\title{
SISTEMI NILAI DAN HUBUNGANNYA DENGAN PROSES PENDIDIDKAN ISLAM
}

\author{
Rustam \\ Guru PAI SMAN 6 Kabupaten Soppeng \\ Email: rustam.sman6soppeng@gmail.com
}

\begin{abstract}
This journal deals with research studies on the value system and its relationship in the process of Islamic education (Axiology Study of Islamic Education). The main problem is how the value system relates to the process of Islamic education and the degree to which the value system relates to the process of Islamic education. This problem is seen with a pedagogical approach and discussed with library research methods, processed by inductive, deductive and comparative methods. Writing this journal intends to find out how the system of values and relationships in the process of Islamic education. The results of the writing indicate that the value system is very important, moreover this system is elements that are regularly and interrelated with the values caused by the subject. The relationship with the Islamic teaching process is very close to value, so it has a reciprocal relationship, meaning the subject with an object or in other words there is a cause for the emergence of everything. Values do not arise by themselves, but there are factors that are prerequisites. The realization of the value system in the process of Islamic education is not only used as a consultation material in the formulation of the objectives of Islamic education, but also a reference in education systems, strategies, and technology as well as educative interactions with the outside world and within Islamic educational institutions.
\end{abstract}

Keywords: Value System, Education, Islam

\section{PENDAHULUAN}

egala sesuatu yang ada dalam alam semesta, langsung atau tak langsung disadari - atau tidak disadari manusia, mengandung nilai-nilai tertentu. Matahari dan 1 bintang-bintang, panas dan air, udara dan cahaya, tumbuh-tumbuhan dan hewan, semua empunyai nilai bagi kehidupan manusia. Demikian pula yang abstrak seperti cinta sesama, kejujuran, pengabdian dan sebagainya.

"Secara umum scope pengertian nilai adalah tak terbatas. Segala sesuatu dalam alam raya adalah bernilai, sedang $\mathrm{n}$ ilai adalah seluas potensi kesadaran manusia, dan variasi kesadaran manusia sesuai dengan individu-individualitas dan keunikan kekpribadiannya, ada manusia yang memuja materi, karena baginya hidup ini ditentukan oleh materi, ada pula manusia yang memuja keindahan, karena didalamnya manusia menikmati kebahagiaan, ada pula manusia yang mengembara dalam kosmos, menjelajajahi angkasa untuk mencari ninlai hidupnya. Banyak manusia yang mengabdikan hidupnya untuk ilmu pengetahuan, ada yang mengabdikan dirinya untuk 
kemanusiaan, semuanya adalah perwujudan kesadran nilai dalam masing-masing pribadi.

Nilai-nilai didalam masyarakat pasti mengalami evaluasi dan penilaian. Dalam analisa teori nilai, kita bedakan dua jenis nilai pendidikan, yaitu nilai instrumental dan nilai intrinsik. Nilai instrumental ialah nilai yang dianggap baik karena beernnilai untuk sesuatu yang lain. Nilai terletak pada konsekuensi pelaksananya dalam usaha mencapai nilai yang lain. Nilai intrinsik ialah nilai yang dianggap baik, tidak untuk sesuatu yang lain, melainkan didalam dan dari dirinya sendiri.

Pendidikan merupakan usaha untuk membina dan mengembangkan pribadi manusia dari aspek rohaniah dan jasmaniah yang berlangsung secara bertahap yang melaalui proses demi proses ke arah tujuan akhir perkembangan/pertumbuhan.

Pendidikan dalam bahasa Yunani dikenal dengan istilah "Paedagogik", sedang dalam bahasa Belanda disebut "Ovpoeding", dalam bahasa Inggeris disebut "Education" dalam bahasa Jerman disebut "Erziehung", dan dalam bahasa latin disebut "Educare" yang dapat diartikan: menumbuhkan, memelihara, membesarkan, menuntun atau mengasuh.

Abdul Fattah Jalal dalam memberikan pengertian pendidikan Islam lebih cenderung menggunakan kata "Ta'lim" dibanding dengan kata: Tarbiyah. Ia memandang bahwa kata “Ta'lim itu lebih cenderung jangkauannya dan lebih utama dengan menggunakan kata: Tarbiyah.

Berdasarkan pemikiran para ahli tersebut diatas, yakni "Pendidikan", dengan jelas bahwa pendidikan Islam itu terjalin dari dua kata, pendidikan dan Islam. Dalam hal ini kata kuncinya adalah Islam Yang berfungsi sebagai sifat, penegas dan pemberi khas bagi kata pendidikan secara khas memiliki ciri Islam, berbeda dengan konsep atau model pendidikan yang lain. Tujuan dari penelitian ini yaitu untuk mengetahui nilai dan hubungannya dengan proses pendidikan Islam.

\section{PENGERTIAN NILAI}

Segala sesuatu yang ada dalam alam semesta, langsung atau tak langsung, disadari atau tidak disadari manusia, mengandung nilai-nilai tertentu. Matahari dan bintangbintang, panas dan air, udara dan cahaya, tumbuh-tumbuhan dan hewan, semua mempunyai nilai bagi kehidupan manusia. Demikian pula yang abstrak seperti cinta sesama, kejujuran, pengabdian dan sebagainya.

"Secara umum scope pengertian nilai adalah tak terbatas. Segala sesuatu dalam alam raya adalah bernilai, sedang $\mathrm{n}$ ilai adalah seluas potensi kesadaran manusia, dan variasi kesadaran manusia sesuai dengan individu-individualitas dan keunikan kekpribadiannya, ada manusia yang memuja materi, karena baginya hidup ini ditentukan oleh materi, ada pula manusia yang memuja keindahan, karena didalamnya manusia menikmati kebahagiaan, ada pula manusia yang mengembara dalam kosmos, menjelajajahi angkasa untuk mencari ninlai hidupnya. Banyak manusia yang mengabdikan hidupnya untuk ilmu pengetahuan, ada yang mengabdikan dirinya untuk 
kemanusiaan, semuanya adalah perwujudan kesadran nilai dalam masing-masing pribadi', ${ }^{1}$

Nilai-nilai sedemikian univeresal dan tak terbatas, tetapi ada pula orang yang membatasi nilai-nilai dalam arti tertentu, yaitu sebagai norma tertentu seperti dinyatakan Celcius:

Dimana ada masyarakat, disana ada hukum. Hukum dalam hal ini dimaksudkan sebagai nilai-nilai, norma, pengatur ketertiban kehidupan sosial. ${ }^{2}$

Perkembangan penyelidikan ilmu pengetahuan tentang nilai-nilai teramat pesat dalam dua abad terakhir ini.

Helegin berpendapat bahwa :

Semesta yang tertib sebagai perwujudan hukum alam yang universal, dan kekal itu terjadi didalam alam raya dan melibatkan semua isinya. Nilai-nilai tidak hanya menururt pikiran dan keinginan manusia secara obyektif. Nilai-nilai itu bersifat obyektif, universal, dari arti bebas daripada pengaruh rasio dan keinginan manusia secara individual. ${ }^{3}$

Nilai bukan merupakan semata-mata untuk memenuhi dorongan intelek dan keinginan manusia. Nilai justeru berfungsi untuk membimbing dan membina manusia supaya menjadi lebih luhur, lebih matang sesuai dengan martabat human dignity.

Nilai dalam pandangan Brubacher tak terbatas ruang lingkupnya. Nilai tersebut sangat erat dengan pengertian-pengertian dan aktivitas mausia yang kompleks, sehingga sulit ditentukan batasannya. Dalam Encyclopedi britanica, dikatakan bahwa:

Nilai adalah suatu penetapan atau suatu kualitas obyek yang menyangkut suatu jenis apresiasi atau minat. Nilai praktis dan efektif dalam jiwa dan tindakan mausia dan melembaga secara obyektif didalam masyarakat. Nilai ini merupakan satu realita yang sah sebagai suatu cita-cita yang benar dan berlawanan dengan cita-cita palsu atau bersifat khayali. ${ }^{4}$

Dalam pandangan Young, nilai diartikan sebagai berikut :

Nilai adalah asumsi-asumsi yang abstrak dan sering tidak disadari tentang halhal yang benar dan hal-hal yang penting. ${ }^{5}$

Dari beberapa pengertian diatas, maka penulis beerkesimpulan bahwa, pengertian nilai adalah suatu penetapan atau suatu kualitas obyek yang menyangkut suatu jenis apresiasi atau minat secara praktis dan efektif dalam jiwa dan tindakan manusia, yang berlangsung secara relatif.

${ }^{1}$ Muhammad Noor Syam, Filsafat Kependidikan dan Dasar Filsafat Kependidikan Pancasila (Cet. IV; Surabaya: Usaha Nasional, 1986), h. 130.

${ }^{2}$ Ibid., h. 131

${ }^{3}$ Ibid

${ }^{4}$ Muhaimin, Abdul Mujib, op. cit., h. 110

${ }^{5}$ Ibid., h. 110. 


\section{BENTUK DAN TINGKATAN NILAI}

"Nilai-nilai didalam masyarakat pasti mengalami evaluasi dan penilaian. Dalam analisa teori nilai, kita bedakan dua jenis nilai pendidikan, yaitu nilai instrumental dan nilai intrinsik. Nilai instrumental ialah nilai yang dianggap baik karena beernnilai untuk sesuatu yang lain. Nilai terletak pada konsekuensi pelaksananya dalam usaha mencapai nilai yang lain. Nilai intrinsik ialah nilai yang dianggap baik, tidak untuk sesuatu yang lain, melainkan didalam dan dari dirinya sendiri', ${ }^{6}$

Nilai instrumental dapat juga dikategorikan sebagai nilai yang bersifat relatif dan obyektif. Dan nilai instinssik keduanya lebih tinggi daripada nilai instrumental.

Ada pula para ahli yangmembedakan bentuk nninlai-nilai bersasar untuk bidang apa nilai itu efektif berfungsi, misalnya; ada nilai hukum, nilai moral, nilai estetika, dan sebagainya.

Edwar Spranger membedakan nilai berdasar interest pribadi manusia ada enam tipe manusia karena kepribadian orang itu menganggap salah satu nilai tersebut paling utama (dominan) bagi hidupnya, nilai-nilai tersebut ialah :

Nilai religi, nilai ilmiah, nilai ekonomi, nilai politik (kekuasaan negara), nilai estetika dan nilai sosial (nilai kemanusiaan). ${ }^{7}$

Pada umumnya masyarakat menganut pendapat bahwa hieraarchi tingkata-tingkat kebenaran, sebab kebenaran itu ialah nilai itu sendiri, apa yang benar itu sekalu mengandung kebaikan, dan sebaliknya kebaikan tingkat religious adalah paling wajar dalam kehidupan manusia. Kewajaran itu bersumber pada proses pertumbuhan kesadaran pribadi sendiri, yaitu mula-mula manusia pada arah perkembangannya hanya menyadari segala sesuatu melalui inderanya. Kemudian baru meningkakt kepada kesadaran yang lebih rasional, yaitu tingkat kesadaran atas nilai-nilai ilmiah.

Sedangkan tingkat religious, disamping merupakan tingkat integritas kepribadian yang mencapai tingkat biddhdi, juga materi. Kebenaran dan kebaikan-kebaikan religious itu bersifat mutlak. Universal, dan suci. Kebenaran dan kebaikan religious meng-atasi rasio, perasaan, keinginan nafsu-nafsu manusiawi. Kebaikan yang bersumber dari religi bersifat universal sosial melampaui subyektivitas golongan, ras, bangsa, tingkat kelas dan sosial.

"Filsafat progresivisme memandang bahwa bentuk nilai tidak dibedakan antara intrinsik dan instrumental, karena kedua jenis nilai tersebut menyebabkan adanaya peerkembangan dan perubahan nilai', 8

Dilihat dari orientasinya dapat dikategorikan dalam empat bentuk, yaitu:

1. "Nilai etis, yang mendasari orientasinya pada ukuran baik dan buruk.

2. Nilai pragmatis, yang mendasari orientasinya pada berhasil dan gagalnya.

3. Nilai effek sensorik, yang mendasari orientasinya pada dosa dan pahala, halal dan

\footnotetext{
${ }^{6}$ Muhammad Noor Syam, Op. cit., h. 137.

${ }^{7}$ Ibid., h. 138

${ }^{8}$ Muhaimin, Abdul Mujib, op. cit., h. 115.
} 


\section{haramnya". 9}

Kemudian sebagian para ahli memandang bentuk-bewntuk nilai beerdasarkan bidang apa yang dinilai, misalnya nilai hukum, nilai estetika, dan sebagainya, nilai etika, dan sebagainya. Namun pada dasarnya nilai-nilai tersebut dapat dikelompokkan menjadi dua bagian, yaitu :

\section{A. Nilai Formal}

Nilai yang tidak ada wujudnya, tetapi memiliki bentuk, lambang, serta simbolsimbol. Nilai terbagi dua macam, yaitu :

1. Nilai sendiri, seperti sebutan "Bapak Lurah " bagi seorang yang memangku jabatan lurah.

2. Nilai turunan, seperti sebutan "Ibu Lurah" bagi seseorang yang menjadi isteri penangku jabatan lurah.

\section{B. Nilai Material}

Nilai yang berwujud dalam kenyataan pengalaman, rohani dan jasmani. Nilai ini terbagi atas dua macam, yaitu :

1. Nilai rohani, terdiri atas nilai logika, nilai estetika, nilai etika, dan nilai religi.

2. Nilai jasmani atau pancaindra, terdiri atas nilai hidup, nilai nikmat, dan nilai guna'" ${ }^{10}$

Nilai material mempunyai wujud karena dapat dirasakan, baik dengan rasa lahir, pancaindera maupun rasa batin-rasio, misalnya :

a. Nilai religi: sanksi, menyangkal, syirik

b. Nilai etika: ramah, serakah, sedekah.

c. Nilai estetika: misik, berpakaian, anggun

d. Nilai logika: cerita, membuktikan, paham

- $\quad$ Nilai religi

Nilai religi mempunyai dua segi, yaitu segi normatif dan segi operatif. Segi normatif menitikberatkan pertimbangan baik dan buruk, benar-salah, hak-bathil, diridhai - dikutuk, sedangkan segi opertif mengandung lima kategori yang menjadi prinsip standarisasi prilaku manusia, yaitu baik, setengah baik, netral, setengah buruk, dan buruk. Hal itu dapat kita jabarkan sebagai berikut :

1. Wajib (baik)

Nilai yang baik dilakukan manusia. Ketaatan akan perintah memperoleh imbalan jasa (pahala), dan kedurhakaan akan mendapatkan sanksi (dosa). Aplikasi nilai ini dalam amaliyah sehari-hari mempunyai ciri tersendiri, misalnya tidak ditentukan waktunay. Dan ada juga yang dibatasi waktu pelaksanaannya (wajib -muaqqod), baik yang sempit (mudhoyyaq), maupun luas waktunya (muywassa'). Disamping itu, ada yang diwajibkan bagi setiap orang ('ain) atau hanya merupakan kewajiban representatif bagi sebagian

\footnotetext{
${ }^{9}$ Ibid.

${ }^{10}$ Ibid., h. 116.
} 
orang (kifayah).

2. Sunnah

Nilai yang setengah baik dikerjakan, sebagai penyempurna terhadap nilai yang baik/wajib, sehingga ketaatannya diberi imbalan jasa dan kedurhakaannya tanpa mendapatkan sanksi.

3. Mubah (netral)

Nilai yang bersifat netral ,mengerjakan atau tidak, tidak berdampakkan imbalan jasa atau sanksi.

4. Makruh (setengah)

Nilai yang sepatutnya untuk ditinggalkan. Disamping berdampak kurang baik, juga memungkinkan terjadinya kebiasaan yang buruk, yang pada akhirnya mengakibatkan keharaman

5. Haram (buruk)

"Nilai yang buruk yang dilakukan, karena membawa kemudaratan dan merugikan diri pribadi, maupun masyarakat pada masyarakat umumnya, sehingga bila subyek melakukannya ddia akan diberi sanksi, baik langsung (di dunia) maupun tidak langsung (di akhirat)". ${ }^{11}$

- $\quad$ Nilai etika

"Nilai etika mempunyai dua matra, yaitu baik dan buruk. Pandangan tentang baikburuk dalan nilai etika sangat beragam. Hal itu karena sudut tinjauannya berbeda-beda, yang dapat kita lihat sebagai berikut :

1. Aliran emperisme

Baik = buruk sesuatu didasarkan atas pengalaman manusi

2. Aliran intuitionisme

Baik-buruk sesuatu ditentukan oleh intuisi seseorang (berupa ilham, bisikan kalbu, naluri atau instink).

3. Aliran rasionalisme

Baik-buruk sesuatu ditentukan atas rasio (akal, pikiran) karena rasio merupakan sumber etika.

4. Aliran tradisionalisme

Baik-buruk sesuatu ditentukan oleh kekonsistenannya dengan tradisi atau adat kebiasaan yang berlaku.

5. Aliran Hedonisme

"Baik buruk sesuatu didasarkan apakah perbuatan itu menghasilkan kebahagiaan. Penilaiannya menitik beratkan pada nilai prakmatis". ${ }^{12}$

"Dapat diketahui bahwa etika itu menyelidiki segala perbuatan manusia kemudian

${ }^{11}$ Ibid., h. 117

12 Ibid., h. 118. 
menetapkan hukum baik atau buruk. Akan tetapi bukanlah semua perbuatan itu dapat diberi hukuman seperti ini, karena perbuatan manusia iut ada yang timbul tiada dengan jehendak, seperti bernafas, detik jantung dan memicingkan mata dengan tiba-tiba waktu berpindah dari gelap ke cahaya, maka inilah bukan pokok persoalan etika, dan tidak dapat memberi huum "baik atau buruk"13

- $\quad$ Nilai estetika

"Nilai estetika mutlak dibutuhkan manusia, karena merupakan bagian hidup manusia yang tak terpisahkan, yang dapat membangkitkan semangat baru, gairah berjuang. Nilai estetika tidak hanya berlaku pada satu institusi, tetapi berlaku dimana saja, pada agama, pendidikan, sosial, politik, hukum, ekonomi, idiologi dan swebagainya. Nilai estetika ini merupakan fenomena sosial yang lahir dari rangsangan cipta dalam rohani seseorang. Ransangan tersebut untuk memberikan ekspresi dalam bentuk ciptadari suatu emosi yang dalam atau pemikiran yang agung, karya estetika akan melahirkan rasa yang disebut dengan "indah". ${ }^{14}$

- $\quad$ Nilai logika

Nilai logika tentunya banyak mencakup pengetahuan, penelitian, keputusan, penuturan, bembahasan, teori atau cerita, yang semuanya termasuk nilai logika. Nilai logika ini bermuara pada pencaharian kebenaran.

Kebenaran dalam nilai logika terletak pada empat hal, yang kesemuanya menimbulkan adanya persamaan dan perbedaan;

Keempat hal itu adalah:

1. Subyek pengamat

Pemahamannya tentang sesuatu dan situasi pisisnya pada saat meneliti obyek

2. Obyek yang diamati

Kenyataan adanya barang atau benda yang diamati

3. Tempat berpijak

Sudut pandang (point of view) dan pangkal tolaknya.

4. Keadaan perantara

Sifat penghubung antara subyek dan obyek, misalnya masalah cahaya, udara, dan jarak". ${ }^{15}$

"Dari keempat hal diatas, muncullah teori-teori tentang kebenaran, yakni kebenaran dari nilai logika. Kebenaran adalah hubungan antara subyek yang menyadari obyek yang disadari. Didalam kebenaran itu terdapat suatu pernyataan (statemen) dan kenyataan (realita). Dengan demikian, kebenaran adalah kesesuaian-kesesuaian antara pernyataan tentang sesuatu dengan kenyataan sesuatu itu sendiri". ${ }^{16}$

\footnotetext{
${ }^{13}$ Ahmad Amin, Etika, Ilmu Akhlak (Cet. VII; Jakarta: Bulan Bintang, 1993), h. 3.

${ }^{14}$ Muhaimin, Abdul Mujib, op. cit., h. 119.

15 Ibid., h. 120.

${ }^{16}$ Ibid., h. 121.
} 
Jadi kebenaran berdasarkan dengan kenyataan yang ada dan dapat dibuktikan adanya tersebut.

\section{SUMBER NILAI DALAM KEHIDUPAN MANUSIA}

Sumber nilai yang berlaku dalam pranata kehidupan manusia dapat digolongkan menjadi dua macam, sebagai berikut:

\section{A. Nilai Ilahi}

Nilai yang dititahkan Tuhan melalui para Rasul-Nya, yang berbentuk takwa, iman, adil, yang diabadikan dalam wahyu Ilahi. Nilai ini bersifat statis dan kebenarannya mutlak. Sebagaimana firman Allah dalam surah Al-An'am ayat 115, yang berbunyi:

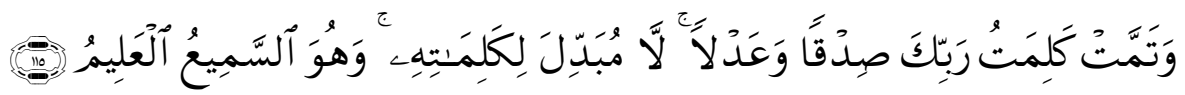

Terjemahnya:

Telah sempurna kalimat Tuhanmu (Al-Quran), sebagai kalimat yang benar dan adil.

Tidak ada yang dapat merobah-robah kalimat-kalimat-Nya dan Dia-lah yang Maha Mendengar lagi Maha Mengetahui. ${ }^{17}$

\section{B. Nilai Insani}

Nilai yang tumbuh atas kesepakatan manusia serta hidup dan perkembangan dari peradaban manusia. Nilai ini bersifat dinamis.

\section{PENGERTIAN PENDIDIKAN ISLAM}

Pendidikan merupakan usaha untuk membina dan mengembangkan pribadi manusia dari aspek rohaniah dan jasmaniah yang berlangsung secara bertahap yang melaalui proses demi proses ke arah tujuan akhir perkembangan/pertumbuhan.

Pendidikan dalam bahasa Yunani dikenal dengan istilah "Paedagogik", sedang dalam bahasa Belanda disebut "Ovpoeding", dalam bahasa Inggeris disebut "Education" dalam bahasa Jerman disebut "Erziehung", dan dalam bahasa latin disebut "Educare" yang dapat diartikan : menumbuhkan, memelihara, membesarkan, menuntun atau mengasuh. ${ }^{18}$

Dalam bahasa Arab pendidikan disebut "Tarbiyah". Hal ini ditemukan beberapa istilah tentang pendidikan sebagai berikut:

1. Raba Yarbu yang berarti: bertambah dan bertumbuh.

2. Rabiya Yarba dengan wazn (bentuk) madda yamuddu, berarti: memperbaiki,

${ }^{17}$ Departemen Agama RI., Al-Quran dan Terjemahnya (Jakarta: Proyek Pengadaan Kitab Suci AlQuran, 1989), h. 207

${ }^{18}$ H. Abdurrahman, Ilmu Pendidikan Sebuah Pengantar Dengan Pendekatan Islam (Cet. I; Jakarta: PT. Al-Qushwa, 1988), h. 1. 
menguasai urusan, menuntun, menjaga dan memelihara. ${ }^{19}$

Dari beberapa pengertian diatas penulis berkesimpulan bahwa pengertian pendidikan adalah bimbingan terhadap perkembangan jasmani rohani siterdidik yang dilakukan oleh seseorang (pendidik) untuk mengalihkan pengalamannya, kecakapan serta keterampilan, untuk melakukan fungsi kehidupannya dengan pergaulan bersama yang sebaik-baiknya. Dengan demikian dapat diketahui bahwa pendidikan pada hakekatnya merupakan usaha manusia melestarikan hidupnya. ${ }^{20}$

Abdul Fattah Jalal dalam memberikan pengertian pendidikan Islam lebih cenderung menggunakan kata "Ta'lim" dibanding dengan kata: Tarbiyah. Ia memandang bahwa kata "Ta'lim itu lebih cenderung jangkauannya dan lebih utama dengan menggunakan kata: Tarbiyah. ${ }^{21}$

Berdasarkan pemikiran para ahli tersebut diatas, yakni "Pendidikan", dengan jelas bahwa pendidikan Islam itu terjalin dari dua kata, pendidikan dan Islam. Dalam hal ini kata kuncinya adalah Islam Yang berfungsi sebagai sifat, penegas dan pemberi khas bagi kata pendidikan secara khas memiliki ciri Islam, berbeda dengan konsep atau model pendidikan yang lain. ${ }^{22}$

Pendidkan Islam merupakan salah satu usaha yang dilaksanakan oleh para pendidik diberbagai sekolah dan juga dalam masyarakat untuk memberikan pembinaan terhadap anak didik dan masyarakat guna mewujudkan generasi Islam yang dapat bertanggung jawab terhadap kelangsungan hidupnya dan diharapkan agar memiliki budi pekerti yang luhur yang dapat menjadi contoh terhadap sesama manusia.

\section{DASAR DAN TUJUAN PENDIDIKAN ISLAM}

Sebagai umat beragama, terutama yang beragama Islam, apabila hendak melakukan sesuatu perbuatan yang menyangkut kebutuhan hidupnya, termasuk didalamnya lapangan pendidikan senantiasa berpatokan kepada Al-Quran dan Sunnah Rasul. Karena kedua dasar tersebut tidak dapat dipisahkan satu dengan yang lainnya. Hal ini menandakan bahwa semua perbuatan dan tingkah laku manusia harus selaras dengan pedoman hidup setiap muslim. Sebagaimana dalam Al-Quran surah Al-Isra' (17) ayat 9, yang berbunyi:

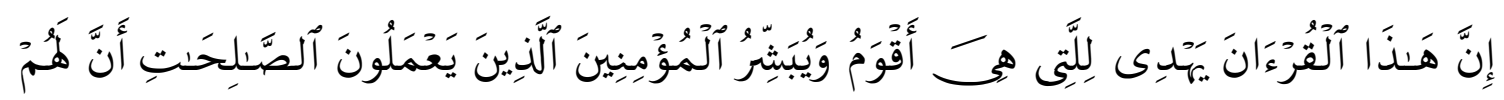

${ }^{19}$ Abdurrahman An-Nahlawi, Ushul al-Tarbiyah al-Islamiyah Wa Asalibuha, yang dialihbahasakan oleh Drs. Harry Noer Ali, dengan judul Prinsip-Prinsip dan Metode Pendidikan Islam, Dalam Keluarga, di Sekolah dan Masyarakat (Cet. II; Bandung: Diponegoro, 1410 H/ 1989 M), h, 31.

${ }^{20}$ Zuharaimi, dkk., Filsafat Pendidikan Islam (Cet. II; Jakarta: Bumi Aksara, 1981), h. 150.

${ }^{21}$ Zakiah Daradjat, Ilmu Pendidikan Islam (Cet. II; Jakarta: Bumi Aksara, 1992), h. 25.

${ }^{22}$ Imam Bawani, Tradisionalisme Dalam Pendidkan Islam (Cet. I; Surabaya; Al-Ikhlas, 1993), h. 59. 


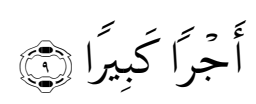

\section{Terjemahnya:}

Sesungguhnya Al-Quran ini memberikan petunjuk kepada (jalan) yang lebih lurus dan memberi khabar gembira kepada orang-orang mukmin yang mengerjakan amal shaleh bahwa bagi mereka ada pahala yang besar. ${ }^{23}$

Selain Al-Quran dan Al-Hadits, juga Ijtihad dapat dijadikan sebagai dasar dalam pendidikan Islam.

Tujuan Pendidikan Islam adalah menanamkan taqwa dan akhlak sertam menegakkan kebenaran dalam rangka membentuk manusia yang berprilaku dan berbudi luhur menurut ajaran agama Islam. Oleh karena itu pendidikan Islam harus mampu menciptakan manusia muslim yang berilmu pengetahuan yang tinggi, dimana iman dan taqwa menjadi pengendali dalam penerapan atau pengalamannya dalam kehidupan sehari-hari.

\section{IMPLIKASI SISTEM NILAI DALAM PROSES PENDIDIKAN ISLAM}

\section{A. Hubungan Nilai dengan Pendidikan Islam}

"Seluruh proses pendidikan, khususnya tujuan pendidikan tidak saja berhubungan dengan nilai, bahkan merupakan proses pembinaan nilai di dalam kepribadian manusia. Karena itu pendidikan dan nilai adalah tak dapat dipisahkan. Pendidikan secara praktis tak terpisahkan dengan nilai-nilai terutama yang meliputi: Kualitas kecerdasan, kerajinan, keturunan, bahkan nilai yang dijabarkan dalam wujud kelas (tingkat, grade), nilai berupa rank, score, mars. Lebih-lebih lagi pendidikan terutama masalah proses pembinaan nilainilai yang bersifat fundamental seperti : nilai-nilai sosial, nilai ilmiah, nilai moral, nilai agama, atau tersimpul di dalam tujuan pendidikan ideal " .24

Proses dan pelaksanaan pendidikan tak mungkin berjalan arah yang hendak dicapai sebagai Garis kebijaksanaan sebagai program dan sebagai tujuan pendidikan. Tujuan pendidikan, baik isinya maupun rumusnya tak mungkin ditetapkan pengertian dan pengetahuan yang tepat tentang nilai-nilai yang kita anggap benar.

"Pendidikan sebagai ilmu praktis yang normatif berarti menetapkan asa norma yang hendak dilaksanakan oleh proses pendidikan Islam, pendidikan Islam menjadi pembimbingpraktis pelaksanaan membina kepribadian manusia. Dan asas-asas normatif yang berlaku di dalam masyarakat dan negara menjadi pendorong, motivasi, bahkan nilainilai itu pula menjadi isi pokok pendidikan. Nilai-nilai dalam masyarakat amat luas scope dan variasinya, nilai-nilai itu heterogen, pluralistris, sebab masyarakat terbentuk atas banyak warga masyarakat, golongan dan tingkat sosial ekonomi, tingkat pendidikan. Oleh

\footnotetext{
${ }^{23}$ Departemen Agama RI. , op. cit. , h. 425-426

${ }^{24}$ Muhammad Noor Syam, op. cit, h. 140.
} 
karena itu pendidikan Islam hendaknya representatif bagi nilai-nilai yang dianut pribadi". ${ }^{25}$

Jika mengerti dan memahami kebenaran, sifat asasinya terdorong pula untuk melaksanakan kebenaran itu, sebaliknya pengetahuan dan pemahaman tentang kebenaran, tanpa melaksanakan kebenaran tersebut, manusia akan mengalami pertentatangan batin, dan konflik psikologis.

"Adapun pendidikan Islam, sebagai suatu konsep ajaran yang diyakini memiliki nilai-nilai tentang kebenaran oleh penganutnya. Pada dasarnya juga merupakan falsafat dan pandangan hidup mereka. Lebih jauh, sebagai konsep Ilahiyat ajaran Islam menururt pandangan muslim mengandung kebenaran yang hakiki. Pendidikan Islam telah mewariskan nilai-nilai yang bersifat mutlak atas kebenarannya, tanpa digunakan lagi. Dengan demikian bahwa nilai itu sebenarnya bersifat relatif dan juga bersifat temporer". ${ }^{26}$

Dengan uraian diatas penulis menyimpulkan bahwa hubungan nilai dengan pendidikan Islam mempunyai relasi timbal balik terhadap proses pendidikan Islam.

\section{B. Manfaat Nilai Dalam Pendidikan Islam}

"Pendidikan Islam sebagai suatu konsep ajaran yang diyakini memiliki nilai-nilai tentang kebenaran oleh penganutnya, pada dasarnya juga merupakan falsafat pandangan hidup mereka. Lebih jauh, sebagai konsep Ilahiyat, Islam menurut pandangan muslim mengandung kebenaran yang hakiki. Pendidikan ajaran Islam menurut pandangan muslim mengandung kebenaran yang hakiki. Keyakinan ini mendorong kaum muslimin untuk menjadikan sumber ajaran Islam mewwujudkan suatu tatanan kehidupan Islami. Dengan demikian, sistem pendidikan sebagai bagian dari tuntunan kehidupan yang dicitacitakan itu, pada hakekatnya tak mungkin terlepas dari keterkaitannya dengan ajaran Islam itu sendiri". ${ }^{27}$

Sistem pendidikan Islam baru dapat dinilai Islami, hanyalah kalau secara serasi dan konsisten dapat diwujudkan sesuai dengan konsep ajaran Alquran dan Hadits. Dalam pandangan Islam, tidak semua nilai yang telah melembaga dalam suatu tataa kehidupan masyarakat, diterima dan ditolak.

"Dalam kehidupan manusia di dunia ternyata memerlukan bimbingan dan penyuluhan dalam menjalankan amal kebaikan. Setiap pelanggaaran akan dibeeri sanksi sesuai dengan perbuaatannya itu dan setiap ketaatan (kebaikan) akan diberi pahala. Disini perlu ditanamkan rasa takut dan harap akan ridha-Nya. Dengan menanamkan rasa takut dan harap ini orang akan diharapkan akan terdorong berbuat baik". ${ }^{2}$

Nilai dalam hal ini sangat penting pernannya dalam menentukan sesuatu apakah itu baik atau tidak baik, dan nilai juga merupakan alat ukur terhadap apa yang dinilai.

\footnotetext{
25 Ibid., h. 141.

${ }^{26}$ Jalaluddin, Usman Said, Filsafat Pendidikan Islam, Konsep dan Perkembangan Pemikiran (Cet. I; Jakarta: PT. Raja Grafindo, 1994), h. 2.

27 Ibid.

${ }^{28}$ Asmaran As., Pengantar Studi Akhlak (Cet. II; Jakarta: PT. Raja Grafindo Persada, 1994), h. 145.
} 


\section{Konsep Pendidikan Dalam Pengembangan Nilai}

Pendidikan Islam yang mempunyai analisis seluruh kehidupan kristalisasi nilainilai yang ingin diwujudkan dalam pribadi manusia. Oleh karena itu, tujuan akhir harus komprehensip, mencakup semua aspek serta terintegrasi dalam pola kepribadian ideal yang bulat dan utuh. Tujuan akhir mengandung nilai-nilai Islami dalam segala aspeknya, yaitu aspek normatif, aspek fungsional, dan aspek operasional.

Secara teoritis pendidikan Islam sebagai ilmu atau disiplin ilmu adalah merupakan konsepsi kependidikan yang mengandung berbagai teori yang dikembangkan dari hipotesa-hipotesa atau wawasan yang berswumber dari kitab suci Al-Quran atau AlHadits. $^{29}$

Dalam proses pendidikan Islam, mempunyai kedudukan yang sangat penting dalam upaya pencapaian tujuan, ia mengandung nilai-nilai yang instrinsik sejalan dengan materi, dan secara fungsional dapat dipakai untuk merelisasikan nilai-nilai ideal yang terkandung dalam tujuan pendidikan Islam.

Dalam proses pendidikan, tujuan akhir merupakan kristalisasi nilai-nilai yang ingin diwujudkan dalam pribadi manusia. Oleh karena itu, tujuan akhir komprehensif, mencakup semua aspek serta terintegrasi dalam pola kepribadian ideal yang bulat dan utuh. Tujuan akhir mengandung nilai-nilai Islam dalam segala aspeknya, yaitu aspek normatif, dan aspek fungsional.

Dengan demikian, maka pendidikan Islam dalam prosesnya harus berlangsung secara kontekstual dangan nilai-nilai yang ingin diwujudkan dalam pribadi manusia. Karena Islam sebagai agama wahyu mengandung sistem nilai yang menjadi pedoman hidup umat manusia dalam segala bidang, termasuk bidang pendidikan. Dalam kehidupan umat manusia baik secara individual maupun sosial, selalu dipengaruhi oleh oleh sistem nilai, baik nilai kultural maupun nilai keagamaan. Sistem nilai yang bersumber pada kultur (kebudayaan) bersifat relatif, sedang sistem nilai agama (agama wahyu) bersifat absolut (mutlak) tidak berubah-ubah mengikuti selera budaya manusia.

Pendidikan Islam mengandung makna internalisasi dan transformasi nilai-nilai Islami ke dalam pribadi manusia dalam upaya membentuk pribadi muslim yang beriman, bertakwa dan berilmu pengetahuan yang amaliyah mengacu kepada tuntutan agama dan tuntunan kedudukan hidup masyarakat.

"Ilmu pendidikan Islam dapat diartikan sebagai studi tentang proses kependidikan yang didasari nilai-nilai ajaran Islam menurut konsepsi filosofis yang bersumberkan kitab suci Al-Quran dan dioperasionalkan Muhammad Rasulullah SAW." 30

Dengan berbagai uraian diatas, maka dapat disimpulkan bahwa pendidikan dalam pengembangan nilai, bersumber dari kitab suci Al-Quran dan Sunnah Nabi Muhammad SAW.

\footnotetext{
${ }^{29}$ H. M. Arifin, Ilmu Pendidikan Islam, Suatu Tinjauan Teoritis dan Praktis Berdasarkan Pendekatan Interdisipliner (Cet. III; Jakarta; Bumi Aksara, 1994), h. 7.

${ }^{30}$ Ibid., h. 109.
} 


\section{KESIMPULAN}

Dari pemaparan singkat diatas maka penulis dapat membuat catatan akhir sebagai esensi pembahasan sebagai berikut:

1. Realisasi sistem nilai dalam proses pendidikan Islam adalah berfungsi untuk membimbing dan membina manusia supaya menjadi luhur, lebih matang seswuai dengan martabat manusia. Dengan demikian juga dalam sistem nilai merupakan acuan, serta interaksi edukatif pada lembaga pendidikan Islam itu sendiri.

2. Dalam hubungan sistem nilai dengan proses pendidikan Islam sangat eratt sekali. Sistem nilai dengan proses pendidikan Islam itu tidak dapat dipisahkan karena keduanya mempunyai hubungan timbal balik terhadap proses pendidikan Islam yang memerlukan pewarisan, pelestarian dan pengembangan melalui pendidikan Islam. Demikain juga proses pendidikan Islam dibutuhkan sistem nilai sehingga pendidikan dapat terarah dalam pelaksanaannya.

\section{DAFTAR PUSTAKA}

Al-Quranul Karim

An-Nahlawi, Abdurrahman, Ushul At-Tarbiyah al-Islamiyah Wa Ashalibuha, Diterjemahkan oleh Drs. Herry Noer Ali, dengan judul Prinsip-Prinsip dan Metode Pendidikan Islam dalam keluarga, disekolah dan di masyarakat, Cet. II; Bandung: Diponegoro, 1992.,

Abdurrahman, H., Ilmu Pendidikan Sebuah Pengantar Dengan Pendekatan Islam, Cet I; Jakarta; Al-husna, 1998.

Arifin, Ilmu Pendidikan Islam, Suatu Tinjauan Teeoritis dan Praktis Berdasarkan Pendekatan Interdisipliner, Cet. III; Jakarta: Bumi Aksara, 1994.

As-Asmaran, Pengantar Studi Akhlak, Cet. II; Jakarta: PT. Raja Grafindo Persada, 1994.

Amin Ahmad, Etika (Ilmu Akhlak), Cet. VII; Jakarta: Bulan Bintang, 1993.

Bawani, Imam, Tradisionalisme Dalam Pendidikan Islam (Cet. I; Surabaya: Al-Ikhlas, 1993), h. 59.

Daradjat, Zakiah, Ilmu Pendidikan Islam, Cet. II; Jakarta: Bumi Aksara, 1992.

Jalaluddin, Usman Said, Filsafat Pendidikan Islam, Konsep dan Perkembangan Pemikiran (Cet. I; Jakarta: PT. Raja Grafindo, 1994), h. 2.

Muhaimin, Abdul Mujib, Pemikiran Pendidikan Islam (Kajian Filosofik dan Kerangka Dasar Operasional), Cet. I; Bandung: Try Genda Karya, 1993.

Noor Syam, Muhammad, Filsafat Pendidikan dan Dasar Filsafat Kependidikan Pancasila, Cet. IV; Surabaya: Usaha Nasional, 1986. 
Pengadaan kitab suci Al-Quran Departemen Agama RI., Al-Quran dan Terjemahnya, Jakarta: Proyek Pengadaan kitab suci Al-Quran, 1989.

Zuhaerini, dkk., Sejarah Pendidikan Islam, Cet. III; Jakarta: Bumi Aksara, 1992. 